\title{
On the Integration of Socialist Core Values in Ideological and Political Education in College
}

\author{
Jing Liang ${ }^{1, a^{*}}$ \\ ${ }^{1}$ The Engineering and Technical College of Chengdu University of Technology, Leshan, China \\ a1035090705@qq.com
}

Keywords: Socialist core values; Ideological and political education; Ways

\begin{abstract}
It is an important and pressing task to apply socialist core values in ideological and political education in college, for they could provide theoretical and practical support. The paper is to analyze the significance of socialist core values in ideological and political education, and propose some ways to apply socialist core values in ideological and political education in college, based on the problems faced by socialist core values in the process of application.
\end{abstract}

\section{Introduction}

Socialist core values are creative achievements in the process of the integration of the Maxim with Chinese traditional culture, and the highly compressed union of the dominant ideology and social moral standards. Therefore, they play a key role in the socialist core value system. According to On Cultivating and Practicing Socialist Core Values issued by the General Office of the CPC Central Committee, we should cultivate and highlight socialist core values in all aspects of national education, which provides policy support and theoretical guidance and ways to follow.

\section{The Significance of Socialist Core Values in Ideological and Political Education in College}

Socialist core values actually give answers to how to pursue goals and values for the nation, society and citizens, which guide the ideological and political education in college and define the task of ideological and political education in college in the construction of modern civil society. Details are illustrated as follows:

Socialist Core Values Define the Responsibilities of College Students. The requirement of socialist core values to the nation is to gather all spiritual powers of people, which is also the goal people struggle for. College students, as the reserve of socialism, should shoulder the responsibilities to realize the Chinese dream of national revival and build a comprehensive well-off society, which are assigned by history, the nation and the people. Socialist core values clearly define the responsibilities of college students, which require them to improve themselves and demonstrate their talents and skills.

Socialist Core Values Guide the Value Orientation of College Students. Socialist core values are the value norms for all people to follow, and the goal which Chinese Communist Party always struggle for. Socialist core values not only demand all people follow the common value norm, but also set the basis for the guidance of value orientation of college students. Thus, it is necessary for colleges in ideological and political education to guide the values of college students, which is beneficial for the students to obtain the core values of freedom, equality, justice and law and order and practice them, developing healthily and all around.

Socialist Core Values Spur College Students on to Good Social Morals. The requirement of socialist core values to individuals is the extension of the requirements to the nation and the society on individuals. That is to say, it is necessary for students to endeavor to have good social morals to take the responsibilities and realize their values. Socialist core values define the morals, which motivate the students to internalize their morals and values and form good habits. 


\section{The Problems Faced by Socialist Core Values in Application}

Traditional Ideological and Political Education Is Unprepared. People could organize and provide information online through networks and provoke their awareness as the main body of the society and the mechanism of development of their cognition and emotion, which is very different from the traditional media and also challenge the traditional education how to instruct socialist core values to students, for whether colleges or social broadcasting, it is a tend to instruct socialist core values in one-to-all methods such as classes, conferences, lectures, reports and so on and people are usually uninterested. It is admitted that people need to have a two-way exchange in ideological system. Therefore, with the development of networks, people tend to be bored in traditional ideological and political education because it is really very hard for them to pay attention to and approve of the value system, compared with the strengths of networks. As a result, socialist core values gradually lose the status of the dominant ideology in networks, if we continue to instruct the core values in traditional ways, and all kinds of non-socialist thoughts and antisocialism would flood the networks. It is obvious that socialists should take the networks as a breakthrough to form a new broadcasting mechanism and platform to instruct socialist core values.

The Bad Effects of Multimedia on Students. All kinds of cultures are prevailing in colleges as the networks are virtual, open and penetrating, which leads to availability of all information, good or bad, and all kinds of values. And this brings a great impact on the education and broadcasting of socialist core values, challenging the dominant ideology, morals and values and the penetration of socialist core values in colleges. Information culture takes the place of the mainstream culture and culture of the backbone, and chooses a daily consciousness as the dominant ideology by diluting the mainstream ideology. To keep the dominant position of socialist core values and effectiveness of instruction, it is necessary to bind socialist core values and networks together in such an environment. We need to endeavor to broadcast the new achievements of socialism and practices in people's life to instruct socialist core values with all kinds of network techniques and methods, and then take the dominant position in networks. Meanwhile, it is recognized that the technology of networks and information culture in western society are relatively more advanced, which render difficulties in broadcasting socialism and challenge it. There are abundant and solid materials in the western society which is helpful to broadcast their value system, especially capitalist values, political cultures and ideology, to other countries around the world. And advanced internet information infrastructure and software technology platform provide technological support during the broadcasting process. However, the internet information technology in China is relatively behind, not only in the updates of information services, but also in the service level and convenience of information service, which would indirectly cause people to compare the networks technology in China and western society and then form preference in logging on lines. Then, in the clash of different cultures and ideologies, it is very hard to stop vice information from broadcasting and forming negative ideologies and multi-value systems, which is a barrier for building up the dominant position of socialist core values and broadcasting socialist core value system.

\section{Ways to Apply Socialist Core Values in Ideological and Political Education in College}

To apply socialist core values in ideological and political education in college is a systematic project by integrating theories with practices and combining knowledge with application. We need to explore how to do it. In the following part, the paper is to propose some ways for consideration.

To Improve Teaching Methods. Ideological and political education is a process to cultivate the cognition, emotion, concept and behaviors of a person. Then, if we want to instruct socialist core values in ideological and political education in college, the first thing to do is to arouse students' interest in core values to adopt them. Good and rational understanding to ideology is the starting point for students to know and adopt an ideology. Teaching in classroom, which could teach a thing systematically to a large group of students, is the major channel to instruct socialist core values. Thus, in a class, if you want to arouse students' interest and motivate them, it is very necessary to know the 
features of students' cognition and learning rules, and design classroom activities and arrange teaching materials and contents according to their mental and physical characteristics. During teaching, students and teachers interact with each other by discussions about the cases in reality, not teacher-centered, but student-centered. The instruction of socialist core values is not only taken place in the courses of ideology, but also in other courses, such as the professional courses and foundation courses. Meanwhile, it is necessary to provide selective course, such as history, morals to broaden the broadcasting channels to instruct socialist core values. By doing so, students would pay attention to socialist core values and willingly learn and adopt them.

To Make Use of Extracurricular Activities. The form and development of a person's morals and values is a process of interaction of many factors, not only a result of a certain educational method. It is essential to make use of extracurricular activities besides classes, for extracurricular activities are very important carriers to the instruction of socialist core values. As precious resources, extracurricular activities could broadcast socialist core values in a specific way without the awareness of students and have an influence on their morals, values, characters and behaviors. Then, how to make use of extracurricular activities? Firstly, it is very important to make full use of college culture, clubs and social practices. For example, the three advocates of socialist core values could be penetrated in the cultivation of college culture and students' spirit, in the singing contests, speeches, debates, in the selection of remarkable college students and so on. By such rich activities, students could obtain right value orientation, shape their characters and consolidate and internalize their understanding and knowledge of socialist core values. Then, it is essential to take full advantage of college papers, college journals, television stations, radio stations and internet platforms to look for a new channel, which is closer to students and more tolerant to differences, to broadcast socialist core values. In other ways, we need to broadcast socialist core values by arousing students' interest, confidence, and sense of pride, and strengthening their political awareness and belongings to the society and nation,

To Highlight Self-education of Students. The process of ideological and political education in college involves the organized class activities of teachers and the self-education of students when they internalize what they have learned. Just as the government requires that ideological and political education in college should bear education and self-education in mind, it is obvious that when colleges play the role of guidance in values, they should also try their best to motivate students to take part in. The self-education of students is an important channel for colleges to instruct socialist core values and also an essential requirement for students to accept ideological and political education and strengthen and consolidate their political awareness. Therefore, it is very important to pay attention to the effectiveness of self-education. But we should respect the students and believe that they can understand and adopt socialist core values by selecting, understanding, experiencing and believing values in the construction of their own values. Besides, we should motivate the students to do self-education. They have a strong desire to get in touch with, know and care the reality, and ability to think alone, analyze problems and explore the nature and rules of things. What we need to do is to motivate them, to help them go consciously through the whole process of self-understanding, self-education, self-evaluation and inspection to internalize their knowledge. Finally, it is necessary to provide a good environment for students to do self-education. Teachers could set good example for students to guide them and help them form decent morals and characters, or give psychological trainings to benefit students in having positive attitudes toward life and right values. Students could encourage each other to experience the beauties in their daily life and communications.

\section{References}

[1] Hao Qi. Lun Shehuizhuyi Hexin Jiazhiguan yu Gaoxiao Sixiang Zhengzhi Jiaoyu de Rong he yu Cujin [J]. China Adult Education, 2015, 15. 
[2] Qin Yu. On the Innovation of the Educational Path of University Ideological and Political Education Integrated with Socialist Core Values [J]. Journal of Jinling Institute of Technology (Social Science), 2013, 3.

[3] Qiu Biao \& Wang Xiaoqing. Ba Shehuizhiyi Hexin Jiazhiguan Rongru Gaoxiao Sixiang Zhengzhi Jiaoyu Quanguocheng [J]. Journal of North China Electric Power University (Social Sciences), 2016, 6.

[4] Pei Yanfeng. Shehuizhiyi Hexin Jiazhiguan Rongru Gaoxiao Sixiang Zhengzhi Jiaoyu DE Sikao[J]. Journal of Sanmenxia Polytechnic, 2014, 6. 